\title{
Short-term effects of clear-cutting on the biomass and richness of epiphytic bryophytes in managed subtropical cloud forests
}

\author{
Jairo Patiño ${ }^{1 *}$, Juana M. GonzÁlez-Mancebo ${ }^{1}$, José M. Fernández-Palacios ${ }^{2}$, \\ José R. Arévalo², Alfredo BermúdeZ², \\ ${ }^{1}$ Departamento de Biología Vegetal (Botánica), Universidad de La Laguna, La Laguna, 38271 Tenerife, Spain \\ ${ }^{2}$ Departamento de Ecología, Universidad de La Laguna, La Laguna, 38206 Tenerife, Spain
}

(Received 23 April 2008; revised version 30 October 2008; accepted 23 February 2009)

Keywords:

Canary Islands /

canopy /

cutting intervals /

epiphytic bryophyte biomass /

laurel forests
Mots-clés :

îles Canaries /

canopée /

intervalles de coupe /

biomasse des bryophytes épiphytes /

forêts de lauriers

\begin{abstract}
- Managed laurel forests in the Canary Islands have undergone clear-cutting with rotation periods of less than $30 \mathrm{y}$. Forest owners have recently requested a drastic reduction in the cutting interval. The effects of this new harvesting cycle on organisms like epiphytic bryophytes are not well known.

- This study investigates how time since last clear-cut, host species and characteristics of tree zones influence the biomass, cover and richness of epiphyte bryophytes in managed laurel forests in La Palma, Canary Islands. Four forest ages $(8,15,25$ and $60 \mathrm{y})$ and three host tree species (Erica arborea, Laurus novocanariensis and Myrica faya) were studied.

- Biomass, cover and richness of bryophytes increased through the chronosequence, both at the level of each plot and overall for L. novocanariensis. Most of the biomass (53\%) and richness (81\%) was concentrated in one of the tree species (L. novocanariensis), in plots for which $60 \mathrm{y}$ had elapsed since the last clear-cutting. Trunks supported greater bryophyte biomass and richness than canopies, even in the oldest plots.

- Our results suggest that the current rotation periods used to manage laurel forests are insufficiently long to allow for complete reestablishment of epiphytic bryophyte assemblages.
\end{abstract}

Résumé - Effets à court terme de la coupe à blanc sur la biomasse et la richesse des bryophytes épiphytes dans des forêts gérées subtropicales.

- Les forêts de lauriers gérées dans les îles Canaries ont subi la coupe à blanc avec des périodes de rotation de moins de 30 ans. Les propriétaires des forêts ont récemment demandé une réduction drastique de l'intervalle de coupe. Les effets de ce nouveau cycle de récolte sur des organismes épiphytes comme les bryophytes ne sont pas bien connus.

- Cette étude examine la façon dont le temps depuis la dernière coupe, les espèces hôtes et les caractéristiques des espèces d'arbres influencent la biomasse, la couverture et la richesse des bryophytes épiphytes dans les forêts gérées de lauriers à La Palma, îles Canaries. Quatre forêts âgées de 8, 15, 25 et 60 ans et trois espèces d'arbres hôtes (Erica arborea, Laurus novocanariensis et Myrica faya) ont été étudiées.

- La biomasse, la couverture et la richesse des bryophytes ont augmenté à travers la chronoséquence, au niveau de chaque parcelle et de l'ensemble de $L$. novocanariensis. La plus grande partie de la biomasse $(53 \%)$ et de la richesse $(81 \%)$ est concentrée sur l'une des espèces d'arbres $($ L. novocanariensis), dans les parcelles pour lesquelles 60 ans se sont écoulés depuis la dernière coupe à blanc. Les troncs supportent une plus grande biomasse de bryophytes et une plus grande richesse que les canopées, même dans les parcelles les plus anciennes.

- Nos résultats suggèrent que les périodes courantes de rotation utilisées pour gérer les forêts de lauriers ne sont pas suffisamment longues pour permettre le rétablissement complet des assemblages des bryophytes épiphytes.

\footnotetext{
*Corresponding author: jpatino@ull.es
} 


\section{INTRODUCTION}

Currently, one of the most important focuses of ecology is an attempt to understand how worldwide deforestation affects the abundance, richness and distribution of organisms. Forestry practices may elicit different responses from each taxonomic group (Gjerde et al., 2005). In this sense, bryophytes are of great value in evaluating the effects of forest harvesting, because many show a high specificity for particular environmental conditions and a low tolerance for habitat perturbations (Dynesius and Hylander, 2007; Humphrey et al., 2002; McGee and Kimmerer, 2002; Moen and Gunnar-Jonsson, 2003; Pereira and Cavalcanti, 2007).

Tropical and sub-tropical cloud forests are characterised by the presence of abundant and species-rich epiphytic bryophyte communities that reflect the prevailing microclimatic conditions (Chia-Chun et al., 2002; Frahm and Gradstein, 1991; González-Mancebo et al., 2004; Pereira and Cavalcanti, 2007) and perform significant ecological functions, including increasing global biological diversity; providing microhabitats; intercepting and retaining soil, rainfall and fog and consequently, influencing both water and nutrient fluxes (Chang et al., 2002; Veneklaas et al., 1990; Wolf, 1993).

Although epiphytic bryophyte biomass has received attention in various forest ecosystems (Edwards and Grubb, 1977; Hofstede et al., 1993; Köhler et al., 2007; Pócs, 1980; Veneklaas et al., 1990; Zippel, 1998), very few studies have directly analysed biomass shifts over time (e.g. McCune, 1993). Furthermore, data on harvesting effects in (sub-)tropical forests with respect to bryophyte biomass are extremely scarce (e.g. Chia-Chun et al., 2002; Köhler et al., 2007; Nadkarni et al., 2004). Regarding bryophyte richness (i.e. number of species) and cover, most studies that have explored epiphytic bryophyte assemblages after harvesting have shown that both parameters increase with forest age (Boudreault et al., 2000; Kantvilas and Jarman, 2004; Lesica et al., 1991; Turner and Pharo, 2005).

However, the study of epiphytic bryophytes is still hampered by challenges in accessing the upper strata of the forest. Most surveys have hence been limited to lowest tree zones, usually sampling only $2 \mathrm{~m}$ above ground level (e.g. Boudreault et al., 2000; González-Mancebo et al., 2004; Kantvilas and Jarman, 2004; McGee and Kimmerer, 2002; Turner and Pharo, 2005). Thus, little information is available on the ecology of canopy-dwelling biota in most forest ecosystems (Köhler et al., 2007; Nadkarni et al., 2004). Further, analysis of the relation between biomass and richness in forests with different ages and host tree species might help us explain the factors that influence the maintenance of epiphytic diversity in (sub-) tropical forests (Nadkarni et al., 2001).

Macaronesian montane cloud forests (hereafter laurel forests) are among the most species-rich regions within the European Union (Fernández-Palacios et al., 2001) and are consequently considered a top-priority area for conservation (Martín et al., 2005; Médail and Quézel, 1997). The rich biological diversity in these laurel forests is evident across a wide variety of taxonomic groups (Martín et al., 2005). Because of moderate temperatures, frequent fog, high precipitation rates and a wide variety of habitats (Fernández-Palacios et al., 2001; Marzol, 2008), epiphytic bryophytes are widespread in these forests (González-Mancebo et al., 2004; Zippel, 1998).

Despite their biological significance, laurel forests in the Canary Islands have a long history of anthropogenic disturbances. Currently, less than $20 \%$ of the estimated pre-human area of this forest ecosystem remains (Del Arco et al., 2006; Fernández-Palacios and Whittaker, 2008). Aborigines, and later the Castilian conquerors, developed subsistence models based on cattle and agriculture, respectively, that led to the logging of many of the mid-altitude laurel forests (Cabrera, 2001; Fernández-Palacios and Whittaker, 2008). During the 20th century, forestry practices switched to clear-cutting (Bermúdez et al., 2007; Fernández-López, 2001). On islands like Tenerife and La Palma, clear-cutting operated on rotation periods of less than $30 \mathrm{y}$ (Naranjo, 2001). The laurel forest products most in demand have been: (i) charcoal from thin stems, (ii) agricultural tools from stems, and (iii) green litter (i.e., leaves and twigs) used as cattle bedding (Bermúdez et al., 2007; Naranjo, 2001).

In recent years, the demand for laurel forest products changed; green litter used for compost production in banana plantations became the most in demand (Bermúdez et al., 2007). Under such circumstances, forest landlords and workers requested a reduction of the cutting intervals have to $7-10 \mathrm{y}$ (Bermúdez et al., 2007). The mean age of laurel forests on islands like La Palma is currently very low (Fernández-López, 2001), and the consequences of this new harvesting cycle on the species-rich communities of epiphyte bryophytes are not well known.

The few quantitative epiphyte studies that have been conducted in this forest ecosystem have focused on bryophyte species composition, mainly in the context of host specificity and climate conditions (Gabriel and Bates, 2005; González-Mancebo et al., 2003a; 2004; 2008a). For these forests, there exists only one survey, which is comprised of visual estimates of epiphytic bryophyte biomass (Zippel, 1998). Most of these studies have been conducted in undisturbed forests and have mainly analysed the composition community associated with lower tree zones.

One exception is previous work that examined the effects of clear-cutting on epiphytic bryophytes from La Palma island analysing shifts in species composition on whole trees in forest stands with different ages after harvesting (Patiño et al., 2009). This study indicated that important negative effects (e.g., prevalence of early-successional species) persist along a chronosequence of $60 \mathrm{y}$. Since there is well-documented registration of previous and current harvesting practices, the study system surveyed by Patiño et al. (2009) provides a unique opportunity to investigate the effects of clear-cutting on the biomass of epiphytic bryophytes. Thus, in the present study, we analyse biomass and its relationships with richness and cover for whole trees of three host species. This study is, to our knowledge, one of the few that attempt to integrate factors such as longevity of substrata and availability of microhabitats for epiphytic bryophytes in the context of harvested subtropical forests. 
The objectives of this research were: (i) to obtain the first direct measurements of bryophyte biomass among whole trees in laurel forests of the Macaronesian region; (2) to evaluate the precision of visual estimate of biomass (previously the only estimates available); and (3) to determine the ways in which abundance (i.e. biomass and cover) and richness of bryophyte communities are influenced by differences in forest age, host tree species and tree zone. Specifically, based on the assumption that the abundance and richness of epiphytic bryophytes increases with forest age, we tested the hypothesis that such an increase in biomass, cover and species number after clearcutting is more strongly affected by forest age (i.e. time since last harvest) than by host identity (i.e. tree species). The main results of our study are used to propose forest management policies.

\section{MATERIALS AND METHODS}

In studies of succession after harvest, the chronosequence approach is commonly used. However, space-for-time substitutions exhibit certain disadvantages, such as possible small differences between the plots with regard to site history, edaphic and microclimatic conditions or the availability of propagules (Foster and Tilman, 2000; Johnson and Miyanishi, 2008; Pickett, 1989). Despite such limitations, chronosequence-based studies have been found to be a useful method for studying temporal succession (e.g. Bermúdez et al., 2007; Foster and Tilman, 2000; Johnson and Miyanishi, 2008).

\subsection{Study area}

We carried out fieldwork from November 2001 to November 2002 in laurel forests on Cumbre Nueva, La Palma, Canary Islands $\left(28^{\circ} 35^{\prime} \mathrm{N}, 17^{\circ} 73^{\prime} \mathrm{W}\right)$. The study area is exposed to the east, receiving prevailing NE winds most of the year. Such winds favour the formation of a strato-cumulus bank where fog drip can even quintuple the rainfall values in summer, when the highest cloud level is ca. 800-900 m a.s.l. (Marzol, 2008). However stands selected are situated over $1200 \mathrm{~m}(1260 \pm 84.85 \mathrm{~m})$. Hence they are not strongly affected by those cloud banks during the summer. The mean annual temperature and precipitation are $13.6^{\circ} \mathrm{C}$ and $960.2 \mathrm{~mm}$, respectively (Del Arco et al., 1999).

The study area covers $3.7 \mathrm{~km}^{2}$, constituting one of the largest continuously harvested and documented laurel forest areas in the Canaries. This swath of land includes a mosaic of forest stands of different ages that have emerged following clear-cutting (Bermúdez et al., 2007). However, the study area does not include any "oldgrowth" forests stands (i.e. stands that have never been clear-cut). On La Palma Island, "old-growth" forest stands are confined to steeper north-eastern slopes within natural reserves that exhibit some dissimilar environmental characteristics, such as lower altitude or differing topography.

The study area was designated to meet the timber and woody biomass requirements of the local human population; in recent years, this has meant green litter (i.e., leaves and twigs) for compost production at banana plantations. Periodically (current harvesting intervals are 7-10 y), the stands are designated for clear-cutting. These short rotation cycles are considered by forest owners and workers to be adequate for economical exploitation of the stand. The stand is totally cleared and cut trees are removed from the site; this is followed by a natural regeneration process. However, in these cleared stands, many snags as well as small broken logs and branches typically remain.

Although laurel forests can show great tree species richness (Arévalo and Fernández-Palacios, 1998), Erica arborea, Myrica faya and Laurus novocanariensis were the only abundant and constant tree species in the study area.We analysed the tree species that separately accounted for $>5 \%$ of the total basal area for each stand studied. We restricted our survey to these three tree species since others (e.g. Ilex canariensis, Persea indica) were much less abundant in the study area and in some stands even absent. Nomenclature follows Acebes et al. (2004) for vascular plants and González-Mancebo et al. (2008b) for bryophytes.

\subsection{Selection and characteristics of forest plots}

Four forest stands with different ages $(8,15,25$, and $60 \mathrm{y}$ after harvesting; hereafter YAH) were selected. Stands covered between 0.5 and 3 ha. Although the present study initially included three other younger forest stands $(0.5,1,3 \mathrm{YAH})$, these ages were eventually excluded from analysis due to the absence of epiphytic colonisation by bryophytes. For more details on the main structural parameters for each stand considered see previous ecological work on vascular plant communities (Bermúdez et al., 2007).

Within each forest stand in the chronosequence, three square plots measuring $25 \mathrm{~m}^{2}$ each $(5 \times 5 \mathrm{~m})$ were established systematically along a transect at regular intervals of 20 to $100 \mathrm{~m}$, depending on the size of the site. We limited this study to plots with homogeneous altitude, exposure, topography, slope, tree development (i.e. diameter at breast height $-1.3 \mathrm{~m}$ above ground level; DBH), tree species composition and density for each phorophyte. To avoid edge effects, each plot was located at least $35 \mathrm{~m}$ from tracks and forest margins. It should be noted, however, that it is unclear whether this sampling strategy provides an environment that is free from edge effects. Edge effects are stronger when stands are isolated or located in a dry environment (Hylander et al., 2005; Moen and Gunnar-Jonsson, 2003; Pereira and Cavalcanti, 2007). Since the stands that we studied were influenced by moist conditions and surrounded by a mosaic of disturbed forest patches, we believe that edge effects were at least partially attenuated.

For each plot, we measured and identified, at the species level, both tree density and tree diameter $(>2.5 \mathrm{~cm} \mathrm{DBH})$. In the chronosequence analysed, Bermúdez et al. (2007) showed that, in general, tree density decreased, while tree height, basal area (i.e. DBH), tree biomass and light incidence increased with forest age. If host species were compared, tree density for $E$. arborea was initially greater than for the other two host tree species. M. faya had the greatest basal area, with the exception of the $60 \mathrm{YAH}$ plots, which showed a dramatic decrease in favour of $L$. novocanariensis (see Bermúdez et al., 2007). These changes in dominant tree species have been related to successional processes favouring shade-tolerant species like L. novocanariensis (Arévalo and Fernández-Palacios, 1998; Arévalo et al., 1999).

\subsection{Sampling}

For each plot in the chronosequence, a total of five trees per host species that formed part of the upper canopy were randomly selected and analysed (Tab. I). This minimum goal was not met in the $60 \mathrm{YAH}$ 
Table I. Mean values and standard deviations per plot through the chronosequence for basal area (BA; $\mathrm{m}^{2}$ ha) and tree height (TH; $\left.\mathrm{m}\right)$ of the sampled trees (see Bermúdez et al., 2007). The three host species are considered separately. ST: total number of sampled trees per forest age; $\mathrm{SN}$ : total number of samples (quadrats) per forest age. For each forest age, the highest value of each structural parameter is shown in bold.

\begin{tabular}{|c|c|c|c|c|c|}
\hline \multirow[t]{2}{*}{ Host tree species } & & \multicolumn{4}{|c|}{ Forest age (years after harvest) } \\
\hline & & 8 & 15 & 25 & 60 \\
\hline \multirow{4}{*}{ Erica arborea } & BA & $2.1 \pm 1.2$ & $5.3 \pm 3.7$ & $10 \pm 5.3$ & $18.3 \pm 2.5$ \\
\hline & $\mathrm{TH}$ & $4.2 \pm 1.2$ & $6.7 \pm 1.1$ & $10.2 \pm 2.1$ & $11 \pm 1.2$ \\
\hline & ST & 15 & 15 & 15 & 7 \\
\hline & SN & 5 & 9 & 240 & 372 \\
\hline \multirow{4}{*}{ Laurus novocanariensis } & BA & $2.6 \pm 0.1$ & $12.5 \pm 8.8$ & $18.7 \pm 8.4$ & $40.1 \pm 26.1$ \\
\hline & $\mathrm{TH}$ & $4.8 \pm 1.3$ & $9.3 \pm 1.2$ & $12.1 \pm 1.4$ & $13.4 \pm 1.5$ \\
\hline & ST & 15 & 15 & 15 & 6 \\
\hline & $\mathrm{SN}$ & 2 & 23 & 368 & 678 \\
\hline \multirow{4}{*}{ Myrica faya } & BA & $2.7 \pm 1.2$ & $20.7 \pm 11.5$ & $32.7 \pm 19.5$ & $11.5 \pm 3.4$ \\
\hline & $\mathrm{TH}$ & $4.5 \pm 1.3$ & $9.2 \pm 1.4$ & $11.4 \pm 2.7$ & $12.4 \pm 1.1$ \\
\hline & ST & 15 & 15 & 15 & 6 \\
\hline & $\mathrm{SN}$ & 7 & 9 & 359 & 364 \\
\hline \multirow{4}{*}{ Total } & $\mathrm{BA}$ & $8.6 \pm 0.9$ & $35.7 \pm 14.9$ & $62.7 \pm 12.5$ & $69.5 \pm 17.3$ \\
\hline & $\mathrm{TH}$ & $4.5 \pm 1.5$ & $8.8 \pm 1.7$ & $10.78 \pm 1.9$ & $12.59 \pm 1.5$ \\
\hline & ST & 45 & 45 & 45 & 19 \\
\hline & $\mathrm{SN}$ & 14 & 41 & 967 & 1414 \\
\hline
\end{tabular}

Standard deviation is related to plot-to-plot variability.

plots (Tab. I). All sampled trees had to fulfil one condition: similar $\mathrm{DBH}$ to the mean DBH calculated for each forest age. Thus, the sampled trees showed a DBH that was within $20 \%$ of the mean DBH. Through this method, we attempted to ensure that the sampled trees had similar historical development. As shown in Table I, biotic parameters from the sampled trees were consistent with the general pattern noted previously at the forest-plot level.

Various sampling strategies were used. Since the three youngest forest plot groups $(8,15,25 \mathrm{YAH})$ had been cut to evaluate the recovery of the laurel forest after harvest in another study performed by Bermúdez et al. (2007), we simply had to supervise this operation to guarantee that bryophytic mass loss would be minimal. Thus, the trees were cut almost at ground level and then carefully lowered to the ground.

The sampling method used at plots at $60 \mathrm{YAH}$ was different; our goal was to conserve a significant part of the oldest forested canopy in the study area. We directly sampled the trunks in the $60 \mathrm{YAH}$ plots using a stepladder that extended from the tree base to a height of $4 \mathrm{~m}$. It was impossible to reach the canopy using single-rope climbing techniques due to the lack of strong upper branches. Of all the main branches that could be cut and lowered safely with a minimal amount of damage upon lowering, two principal branches per tree were randomly selected for removal. The cut was performed close to the branch's junction with the trunk. Of the 54 main branches counted for this forest age (60 YAH), 38 (70\%) were sampled. The total number of main branches per tree ranged between two and four $(2.7 \pm 0.7)$; consequently, at least $50 \%$ of the branches on each tree were sampled.

This selection method could have biased our results towards an overestimate of bryophyte abundance, since the main (i.e. older) branches usually support greater biomass than younger ones (Hofstede et al., 1993). However, other researchers have considered this method adequate for investigating and obtaining rough estimates of epiphyte biomass on upper branches (Köhler et al., 2007; Nadkarni et al., 2004). In addition, because most non-sampled branches were of similar perimeter, development and shape in comparison to those studied, and also exhibited great similarity in their epiphytic cover, we consider our posterior estimations reasonable.

We stratified the trees using a modification of the classical method (Johansson, 1974). We distinguished five zones on each tree: tree base; trunk; and inner, middle and outer canopy. We then divided each tree into two aspect zones (NE and SW sides; see González-Mancebo et al., 2004). Then, considering each aspect zone separately and starting at the bottom of each tree zone, we sampled at $10 \mathrm{~cm}$ intervals until we reached the top of each tree zone. To take bryophyte samples, we used $100 \mathrm{~cm}^{2}$ quadrats whose sides were modified in length depending on the perimeter of the tree zone (i.e. trunk, branch or twig). For each quadrat, we noted forest age, tree species, tree zone, aspect zone, height above ground and total cover; the latter was estimated visually in the field and the percentage of total cover occupied by each bryophyte species was calculated afterwards in the laboratory.

\subsection{Bryophyte biomass}

After separating organic debris and bark fragments, all quadrats were oven dried at $80{ }^{\circ} \mathrm{C}$ for $24 \mathrm{~h}$ and weighed in the laboratory to estimate the total epiphytic bryophyte biomass. Since the trees at 8 , 15 and $25 \mathrm{YAH}$ and the trunks at $60 \mathrm{YAH}$ were sampled completely, the first extrapolation was made for sections of the canopy at $60 \mathrm{YAH}$. Thus, for these extrapolations of biomass, we followed a method very similar to that employed by Köhler et al. (2007). The total epiphytic bryophyte biomass of the canopy per tree was estimated by multiplying the mean biomass of epiphytic bryophytes of the two sampled branches by the total number of main branches within the crown.

Total epiphyte biomass at the forest-plot level was obtained by multiplying the mean biomass estimated for the sampled trees by the 
Table II. Spearman Rank correlation coefficients for the relationships among the bryophyte parameters and the environmental variables at the plot level. Each host tree species was considered separately $(n=36)$. Names of tree species indicate basal area of Erica arborea, Laurus novocanariensis and Myrica faya respectively. Values marked in bold denote strong correlation $(R>0.7, P \leq 0.001)$.

\begin{tabular}{|c|c|c|c|c|c|c|c|c|c|c|}
\hline & 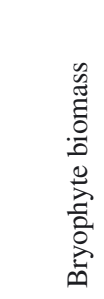 & 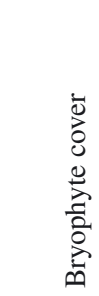 & 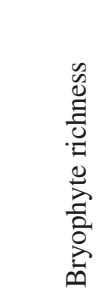 & 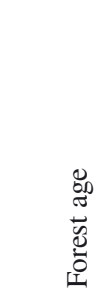 & 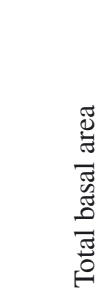 & 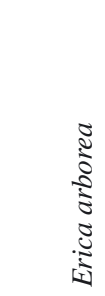 & 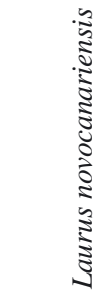 & 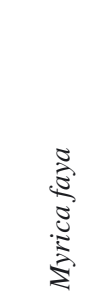 & 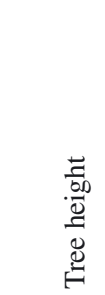 & 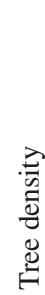 \\
\hline Bryophyte biomass & 1 & & & & & & & & & \\
\hline Bryophyte cover & 0.954 & 1 & & & & & & & & \\
\hline Bryophyte richness & 0.884 & 0.906 & 1 & & & & & & & \\
\hline Forest age & 0.947 & 0.894 & 0.831 & 1 & & & & & & \\
\hline Total basal area & 0.827 & 0.795 & 0.754 & 0.404 & 1 & & & & & \\
\hline Erica arborea & ns & 0.879 & ns & 0.462 & 0.462 & 1 & & & & \\
\hline Laurus novocanariensis & 0.802 & 0.433 & 0.392 & 0.375 & 0.498 & 0.523 & 1 & & & \\
\hline Myrica faya & ns & ns & ns & ns & 0.437 & 0.398 & 0.398 & 1 & & \\
\hline Tree height & 0.793 & 0.760 & 0.701 & 0.939 & 0.928 & $\mathrm{~ns}$ & 0.374 & 0.348 & 1 & \\
\hline Tree density & -0.924 & -0.885 & -0.809 & -0.471 & -0.471 & -0.472 & -0.356 & $\mathrm{~ns}$ & -0.937 & 1 \\
\hline
\end{tabular}

ns $=$ Non-significant correlations.

total number of trees in that plot. Such estimates were made separately for each host species within each plot. To calculate the total number of trees, we considered only those trees with a DBH within $20 \%$ of the mean DBH calculated for each plot (Bermúdez et al., 2007). As noted previously, we used this criterion to remove possible artefacts caused by illegal cuttings or natural events (e.g., storms). All of the large trees in each plot were considered initially because each had a DBH within $20 \%$ of the mean. However, our epiphyte biomass estimates should be regarded as conservative because natural young trees that exhibited low epiphytic coverage were overlooked. Shrubs were usually free of epiphytes and were therefore assumed not to contribute epiphytic bryophyte biomass to the total.

We also recorded background data on the bryophyte biomass per hectare $\left(\mathrm{kg} \mathrm{ha}^{-1}\right)$. First, we obtained estimates of tree density for each host species (per hectare) from data provided by Bermúdez et al. (2007). Then, to extrapolate biomass to the hectare level, we multiplied the mean biomass estimated for the sampled trees by the mean density of trees per hectare; each forest age and host species were considered separately. We are aware that our estimates calculated at the hectare level probably suffer from substantial imprecision but they may nonetheless exhibit a clear theoretical profile.

\subsection{Data analysis}

To examine significant differences in bryophyte biomass, cover and species richness (means) per plot in order to test the effect of forest age, host tree species and zone within the tree, we used two nonparametric analyses: the Kruskal-Wallis test and a posterior MannWhitney U test (for differences between pairs). Before conducting these tests, the normal distribution hypothesis of our data was rejected using a Wilks-Shapiro test with a significance level of $P=0.05$. Although we considered our results statistically significant if $P<0.05$, a Bonferroni multiple test correction was later employed to adjust significance levels (Legendre and Legendre, 1998). In this way, we tried to limit the possibility of inferring an effect where none existed (type I error). Non-parametric variance analyses were performed using SPSS for Windows (Release 17, SPSS Inc., 2008).

Ordination methods are very useful for revealing the relationships between community variation and environmental variables (Minchin, 1989), and they can be used to evaluate trends through time as well as space (ter Braak and Šmilauer, 2002). However, since using many factors in ordination analyses can introduce bias in the results, we used Spearman correlations to identify collinearity among characteristics at the forest-plot level.

Of the plot features we surveyed (tree density, tree height, basal area, tree biomass, photosynthetic biomass and light incidence; Bermúdez et al., 2007), we used only the most weakly age-associated forest features for our posterior ordination analyses (results not shown). At the plot level, a correlation coefficient $(R)>0.7$ was considered evidence of serious collinearity; in such cases, we chose the variable that was most relevant to bryophytes and the ecosystem. Thus, we included only basal area and tree density, for which the correlations with forest age were all relatively low $(R<0.471 ; P<0.05$; Tab. II).

Principal components analysis (PCA) performed using Canoco 4.5 (ter Braak and Šmilauer, 2002) was selected because it assumes a linear relationship with the underlying environmental gradient (Minchin, 1989). This is consistent with the expected pattern of epiphytic bryophyte abundance after forest harvesting. In PCA (ter Braak and Šmilauer, 2002), the relationships between a set of environmental variables and an ordination score are plotted on ordination diagrams, with arrows depicting the direction and magnitude of each variable considered.

At the plot level, summary statistics of bryophyte parameters (i.e. biomass and richness), zone within tree (i.e. percentage of each tree zone covered by bryophytes) and forest characteristics (i.e. forest age, basal area and tree density) were combined, considering each host tree species separately. A PCA bi-plot focused on inter-sample distance was used to examine the differences among plots within each 
forest age class according to the main plot-level environmental and biotic features.

Reported shortcomings of PCA involving curvilinear distortion (Minchin, 1989) were not an issue for the current study due to the low heterogeneity of these data; the gradient length of the ordination did not exceed 2.5 standard deviations, suggesting that the linear model of PCA was appropriate (ter Braak and Šmilauer, 2002). This was confirmed by similar patterns and interpretations when using nonmetric multidimensional scaling (NMDS; Clarke 1993) with the Euclidean distance measure (not shown). NMDS was performed in PRIMER v 6 (Clarke and Gorley, 2006).

The Spearman rank correlation test implemented using the SPSS package was also used at the plot level to assess the relationships between summary bryophyte statistics (biomass, cover and richness) through time. For all correlations, we used data from each host species separately and considered a probability level of $P<0.05$ to be significant. The correlations of forest features with bryophyte parameters and PCA scores are reported at the plot level.

\section{RESULTS}

We recorded a total of 47 bryophyte species, 28 mosses and 19 liverworts. Hypnum uncinulatum and Frullania teneriffae were the most common species in the younger forest plots (8, $15 \mathrm{YAH}$ ) and on E. arborea and $M$. faya in the 60 YAH plots (Patiño et al., 2009). On L. novocanariensis in the 60 YAH plots, the most abundant species were Porella canariensis, Neckera intermedia, Isothecium myosuroides and Cryptoleptodon longisetus. Lists of species and analyses of our data regarding community composition are reported elsewhere (Patiño et al., 2009).

\subsection{Forest age}

The 60 YAH plots contributed most of the bryophyte biomass (85\% of all biomass), cover (76.64\% of all cover) and species richness (81\% of all species). These $60 \mathrm{YAH}$ plots were followed by forests with 25 YAH $(14.01 \%$ of biomass, $16.15 \%$ of cover and $71 \%$ of richness). In general, forests with 8 YAH $(0.03 \%$ of biomass, $4.27 \%$ of cover and $19.14 \%$ of richness) and 15 YAH plots $(0.48 \%$ of biomass, $4.94 \%$ of cover and $40.42 \%$ of richness) contributed minimal percentages, especially with regard to biomass. Biomass (Kruskal-Wallis test; $H=31.52$; d.f. $=11 ; P<0.001)$, cover $(H=28.21 ;$ d.f. $=11 ; P<0.001)$ and richness $(H=25.76$; d.f. $=11 ; P<0.001)$ of epiphytic bryophytes increased significantly during the chronosequence (Fig. 1). Of all the pairwise comparisons, only richness levels between the 25 and $60 \mathrm{YAH}$ plots were not significantly different (Fig. 1.3).

\subsection{Host tree species}

The differences in bryophyte biomass, cover and richness among the three host tree species in each forest age were
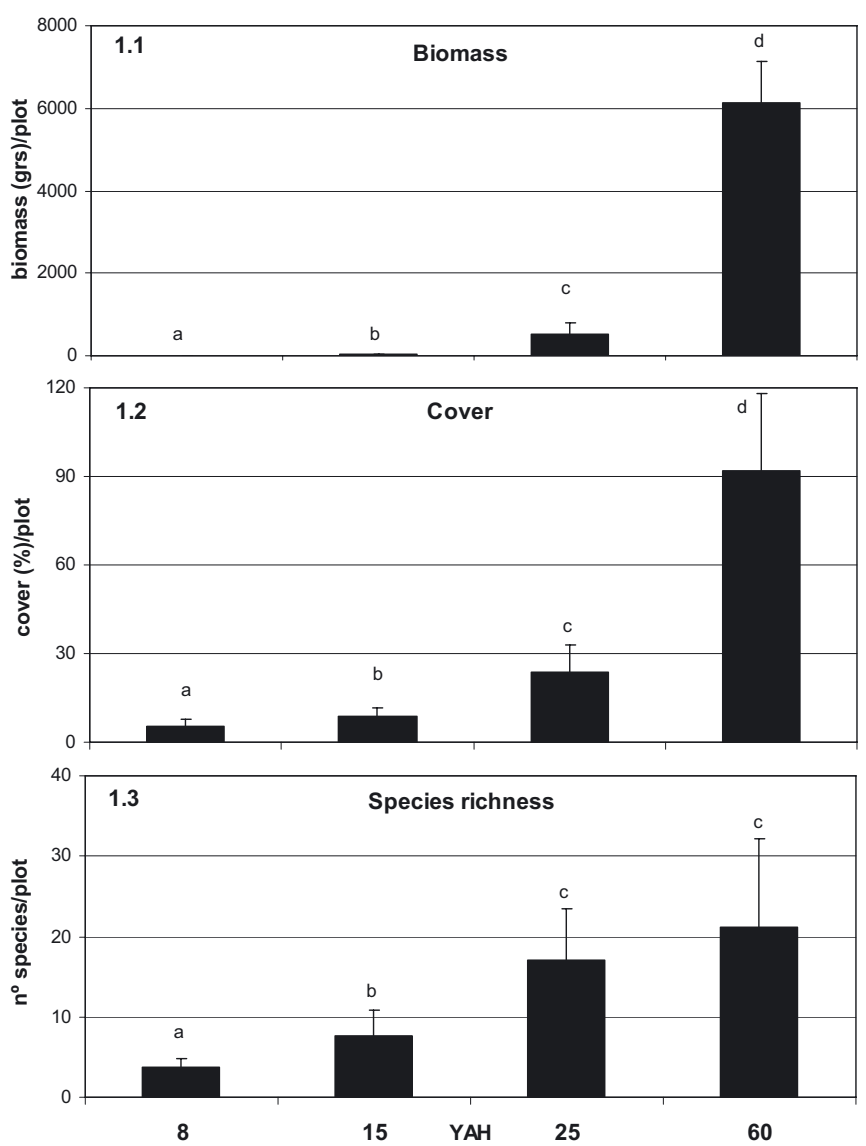

Figure 1. Mean values and standard deviations per plot through the chronosequence for the three parameters of epiphytic bryophytes: (1.1) biomass (g/plot); (1.2) cover (\% cover/plot); and (1.3) species richness (number of species/plot). Identical letters above the bars indicate non-significant differences. YAH = years after harvest.

significant (Kruskal-Wallis test; at least $H>20.75$; d.f. $=$ 8; $P<0.001)$. Such differences were more evident in the 60 YAH plots (Kruskal-Wallis test; $H>45.38$; d.f. $=8$; $P<0.001$ ). Bryophyte biomass (Fig. 2.1) was significantly higher on L. novocanariensis (53\% of all biomass), followed by $E$. arborea $(20 \%)$ and $M$. faya $(13 \%)$; these proportions were recorded at $60 \mathrm{YAH}$. In contrast, $M$. faya and L. novocanariensis had significantly higher bryophyte cover at $60 \mathrm{YAH}$ (Fig. 2.2). In the 60 YAH plots (Fig. 2.3), species richness peaked on L. novocanariensis ( $81 \%$ of all species), while $E$. arborea exhibited the poorest species richness (23\%). At this forest age, species richness decreased weakly for $E$. $a r$ borea and on M. faya (Fig. 2.3).

When each host species was analysed separately, biomass and cover differed significantly throughout the chronosequence (Kruskal-Wallis test; at least $H>16.23$; d.f. $=11$; $P<0.01)$. Most of the possible consecutive comparisons between pairs of forest ages for each host tree species were also significant for biomass and cover, especially between 25 and $60 \mathrm{YAH}$ (not shown). For the three host species, richness also differed significantly over time $(H>14.83$; d.f. $=11$; 

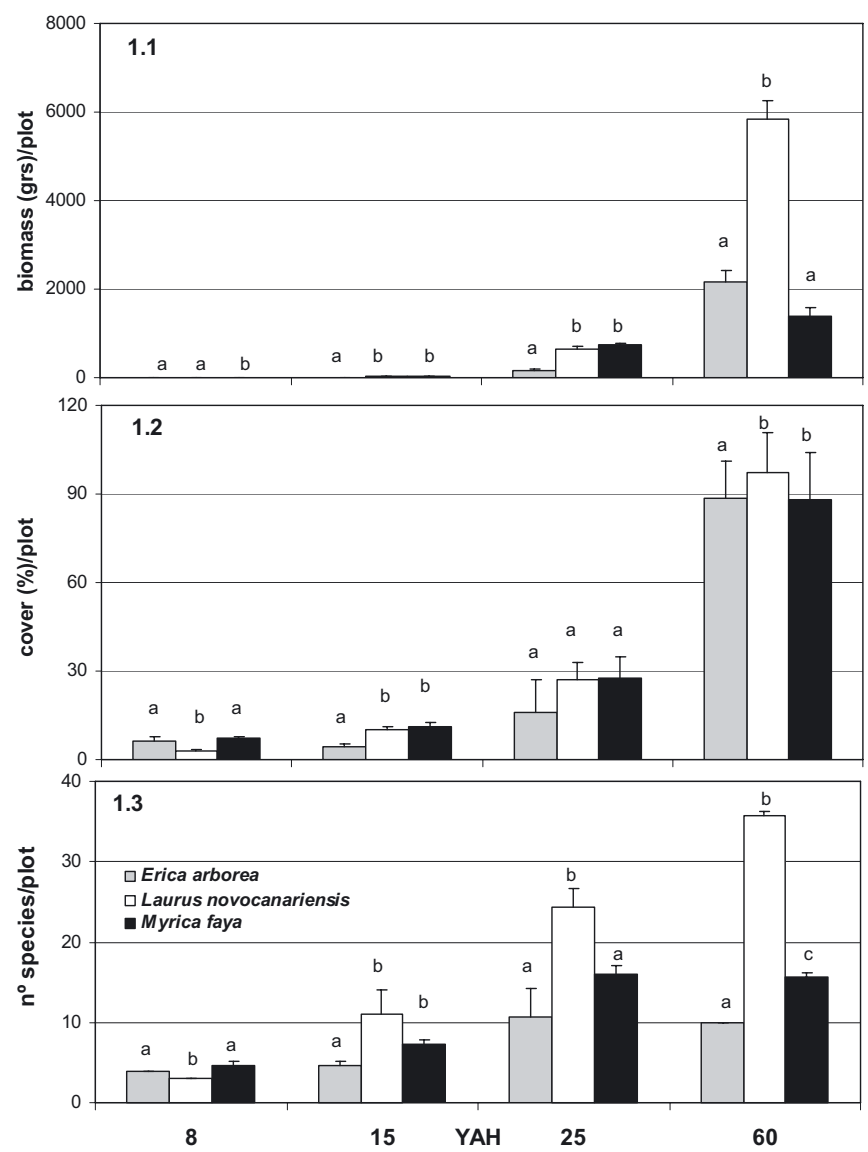

Figure 2. Mean values and standard deviations per plot through the chronosequence for the three parameters of epiphytic bryophytes: (1.1) biomass (g/plot); (1.2) cover (\% cover/plot); and (1.3) species richness (number of species/plot). The three host tree species (Erica arborea, Laurus novocanariensis, Myrica faya) are showed separately. Identical letters above the bars indicate non-significant differences. $\mathrm{YAH}=$ years after harvest.

$P<0.01)$. However, we failed to find significant richness differences between the 25 and $60 \mathrm{YAH}$ plots for E. arborea and $M$. faya (not shown).

\subsection{Zone within the tree}

Considering zones within the tree (Tab. III), the greatest proportion of bryophyte biomass and cover for each tree species was located on trunks at $60 \mathrm{YAH}$. In these oldest plots, bryophytes colonised young branches of the outer canopy only on L. novocanariensis (Tab. III). The middle and inner canopy were the uppermost zones occupied on M. faya and $E$. arborea, respectively. Inner-canopy biomass increased strikingly on L. novocanariensis, while it was much lower on M. faya at $60 \mathrm{YAH}$ than at $25 \mathrm{YAH}$. For the younger forest plots (8-15 YAH), biomass was mainly limited to the tree bases. With respect to biomass and cover, significant differences were detected between tree zones for the three host species (Kruskal-Wallis test; d.f. ranging 8 from to 14; at least $H>28.47 ; P<0.001)$.

Species richness gradually diminished from trunk bases towards the highest zones colonised by bryophytes (Tab. III), except in the oldest plots. In the oldest plots, the trunks of all host tree species were richer than the tree bases. Differences in richness among the tree zones were significant for all three host tree species (Kruskal-Wallis test; d.f. ranging 8 from to 14 ; at least $H>17.21, P<0.007)$.

Total estimations of bryophyte biomass $\left(\mathrm{kg} \mathrm{ha}^{-1}\right)$ contained in each distinguished tree zone for each forest age are shown in Table IV. The two youngest forests ( 8 and $15 \mathrm{YAH})$ presented very low estimates: 0.5 and $7 \mathrm{~kg} \mathrm{ha}^{-1}$, respectively. The 60 YAH forests supported a total of $\sim 1200 \mathrm{~kg} \mathrm{ha}^{-1}$ (of bryophytes), while the $25 \mathrm{YAH}$ plots displayed only $\sim 200 \mathrm{~kg} \mathrm{ha}^{-1}$. In the oldest forests, trunks (including tree base) supported $\sim 1100 \mathrm{~kg} \mathrm{ha}^{-1}$ (Tab. IV), whereas canopies contained only $\sim 130 \mathrm{~kg} \mathrm{ha}^{-1}$. These estimates were much lower in the 25 YAH forests, although the differences between trunks and canopies were similar (Tab. IV). Total species richness (Tab. IV) followed a parallel trend, except in the tree bases, where the highest richness was attained at $25 \mathrm{YAH}$.

\subsection{Relationships of bryophytes with environmental variables}

Forest age showed correlations with forest structural features (Tab. II). However, we chose not to discard some of these variables due to the differences observed with respect to tree density and basal area for each host species across the chronosequence, and because of the associated lower or null collinearity. Tree height was discarded since it was strongly correlated with other variables (basal area and tree zone, respectively; see Tab. II).

As revealed by PCA ordination (Fig. 3), certain factors could distinguish between the plots with regard to host tree species and time after clear-cutting: bryophyte parameters (biomass and richness); the percentage of each tree zone covered by bryophytes; and the selected variables (forest age, total basal area, basal area of each host species and tree density). Thus, Laurus novocanariensis at $60 \mathrm{YAH}$ showed a positive correlation with axis 1 while the group of younger plots $(8,15$, $25 \mathrm{YAH}$ ) and of Erica arborea and Myrica faya at $60 \mathrm{YAH}$ exhibited a weaker correlation (Fig. 3). PCA scores on axis 1 showed a strong correlation with forest age $(R=0.966$, $P<0.001)$, tree density $(R=-0.954, P<0.001)$ and basal area of L. novocanariensis $(R=0.930, P<0.001)$. Axis 2 was determined primarily by middle canopy $(R=0.798$, $P=0.001)$, trunk $(R=-0.705, P=0.001)$ and tree base $(R=-0.654, P<0.002)$; most correlations for axis 2 were weaker than these (Fig. 3).

In general, epiphytic bryophyte biomass, cover and richness were strongly and positively correlated (Fig. 4; Tab. II), especially when correlations were made using each forest age separately (at least $P<0.001$; results not shown). This net correlation was stronger for cover and biomass than for all 
Table III. Total bryophyte biomass ( $\mathrm{kg} / \mathrm{ha}$ ), cover (percentage of cover $/ 25 \mathrm{~m}^{2}$ ) and species richness (number of species $/ 25 \mathrm{~m}^{2}$ ) through the chronosequence. The stratification system is considered for each host tree species, separately. The highest value for each tree zone is shown in bold and dashes indicate value of zero.

\begin{tabular}{|c|c|c|c|c|c|c|c|c|c|c|c|c|c|}
\hline \multicolumn{2}{|l|}{ Host species } & \multicolumn{4}{|c|}{ Erica arborea } & \multicolumn{4}{|c|}{ Laurus novocanariensis } & \multicolumn{4}{|c|}{ Myrica faya } \\
\hline & Years after harvest & 8 & 15 & 25 & 60 & 8 & 15 & 25 & 60 & 8 & 15 & 25 & 60 \\
\hline \multirow{4}{*}{ Biomass $^{a *}$} & Tree base & 0.1 & 0.2 & 3.3 & 47.2 & 0.1 & 3.7 & 41.7 & 117.1 & 0.3 & 3.1 & 13 & 23.3 \\
\hline & Inner canopy & - & - & 0.2 & 23.3 & - & - & 6.6 & 109.2 & - & - & 28.3 & 6.3 \\
\hline & Middle canopy & - & - & - & - & - & - & 1.4 & 7.1 & - & - & - & 0.1 \\
\hline & Outer canopy & - & - & - & - & - & - & - & 1.1 & - & - & - & - \\
\hline \multirow{4}{*}{ Cover $^{\mathrm{a}}$} & Trunk & - & - & 10.6 & 97.7 & - & 1.0 & 15 & 94.4 & - & - & 20.5 & 97.9 \\
\hline & Inner canopy & - & - & 3.5 & 8.3 & - & - & 13.2 & 60.7 & - & - & 15.7 & 28.7 \\
\hline & Middle canopy & - & - & - & - & - & - & 12.6 & 25.1 & - & - & 1 & 1 \\
\hline & Outer canopy & - & - & - & - & - & - & - & 15.3 & - & - & - & - \\
\hline \multirow{2}{*}{ Species richness ${ }^{\mathrm{a}}$} & Tree base & 4 & 4.7 & 7.7 & 5.3 & 3 & 11 & 15 & 20.7 & 4.7 & 7.3 & 11.7 & 8.7 \\
\hline & Outer canopy & - & - & - & - & - & - & - & 3 & - & - & - & - \\
\hline
\end{tabular}

${ }^{\text {a }}$ Mean values per plot; standard deviations were not included to improve the visualisation of the table.

* Values at the hectare level were calculated using the estimation procedures explained in the bryophyte biomass Section 2.4.

Table IV. Total bryophyte biomass $\left(\mathrm{kg} \mathrm{ha}^{-1}\right)$ and species richness (number of species per $75 \mathrm{~m}^{2}$ ) contained in each distinguished tree zone within each forest age class. The highest value for each tree zone and forest age is shown in bold and dashes indicate value of zero.

\begin{tabular}{|c|c|c|c|c|c|}
\hline \multicolumn{2}{|c|}{$\begin{array}{l}\text { Zones within } \\
\text { the tree }\end{array}$} & \multicolumn{4}{|c|}{ Years after harvest } \\
\hline & & 8 & 15 & 25 & 60 \\
\hline \multirow{7}{*}{ Biomass } & Tree base & 0.5 & 7.1 & 58 & 187.6 \\
\hline & Trunk & - & 0.1 & 110.9 & 934.4 \\
\hline & Inner canopy & - & - & 35.2 & 122.4 \\
\hline & Middle canopy & - & - & 1.4 & 7.2 \\
\hline & Outer canopy & - & - & - & 1.1 \\
\hline & Total & 0.5 & 7.1 & 205.4 & 1252.8 \\
\hline & Tree base & 9 & 19 & 27 & 27 \\
\hline \multirow{5}{*}{$\begin{array}{l}\text { Species } \\
\text { richness }^{\mathrm{a}}\end{array}$} & Trunk & - & 1 & 26 & 34 \\
\hline & Inner canopy & - & - & 20 & 27 \\
\hline & Middle canopy & - & - & 14 & 17 \\
\hline & Outer canopy & - & - & - & 15 \\
\hline & Total & 9 & 19 & 34 & 40 \\
\hline
\end{tabular}

a Species richness is obtained from the sum of the species that occurred in the three plots of each forest age.

the comparisons with richness (Fig. 4). Richness, cover and biomass of epiphytic bryophytes were positively correlated with the majority of forest features, especially with forest age (Tab. II); these three parameters showed a strong nega- tive relationship with tree density. The relationship between bryophyte biomass and basal area in $L$. novocanariensis was strongly positively correlated. Similar results were obtained for the relationship between bryophyte cover and basal area in E. $\operatorname{arborea}$ (Tab. II).

\section{DISCUSSION}

Most of studies of forestry effects on epiphytic bryophyte communities have primarily analysed the lower tree zones and compositional data (e.g. Kantvilas and Jarman, 2004; McGee and Kimmerer, 2002; Turner and Pharo, 2005) and compositional data (e.g. Boudreault et al., 2000; Patiño et al., 2009). Ours is one of the few studies that combines time since forestry activity with within-canopy direct sampling and host identity with the aim of whole-forest extrapolation of bryophyte biomass.

\subsection{Influence of forest age and zone within the tree}

Our study did not detect epiphytic colonisation in stands with ages ranging from 0.5 to $8 \mathrm{y}$, and we found no notable rise in bryophyte community abundance until $25 \mathrm{YAH}$. The earliest epiphytic bryophyte colonisation in the laurel forests that we observed seemed to require a time period of at least $8 \mathrm{y}$ since the last harvest. Earlier studies on forestry effects have shown significant differences (i.e. forest structure and resource 


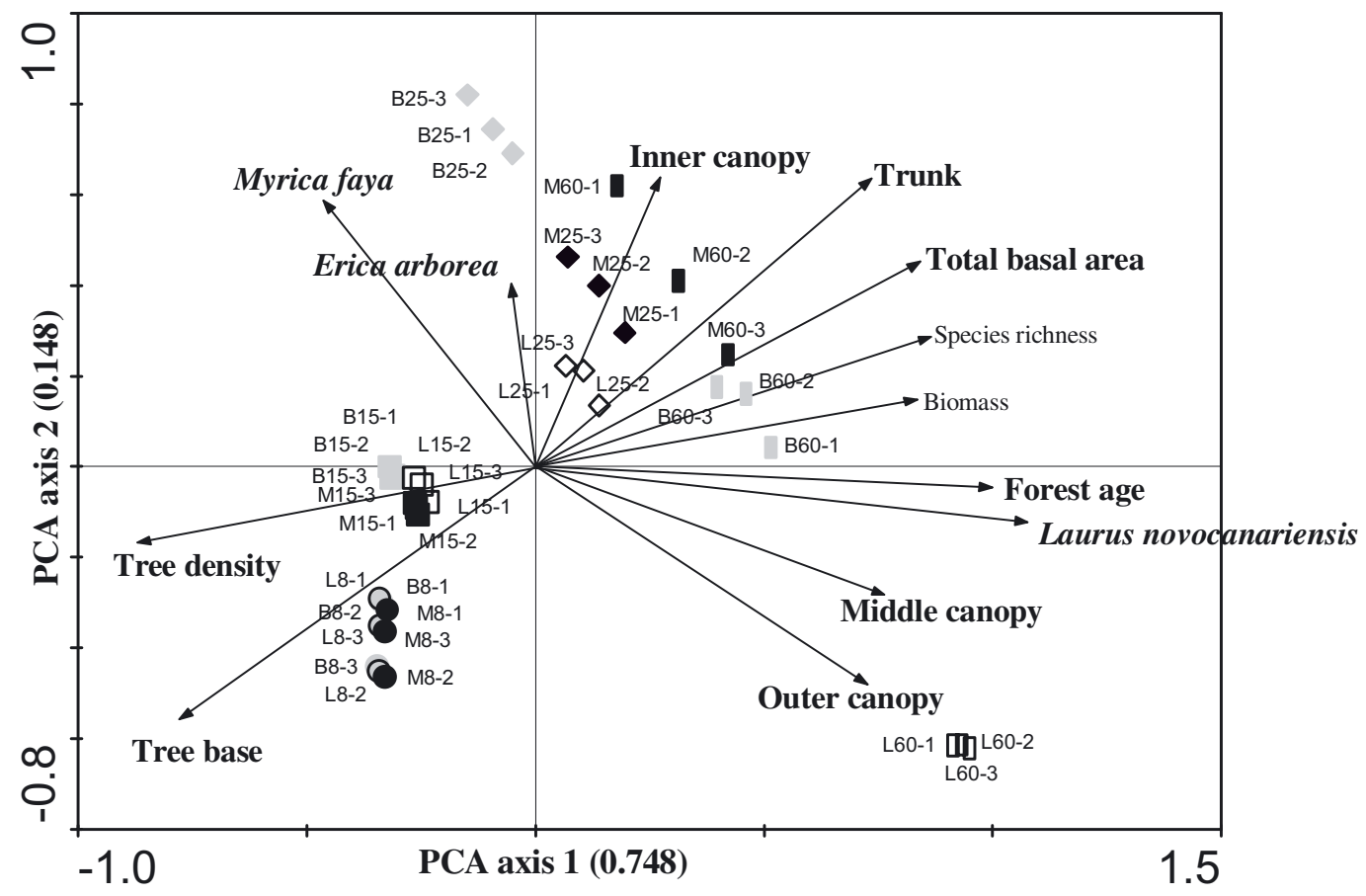

The eigenvalues are indicated between brackets.

Figure 3. Principal Components Analysis of bryophyte parameters (biomass and species richness), forest age, basal area total and of each host tree species, tree density and percentage of each tree zone covered by bryophytes. Each symbol represents the combination of bryophyte statistics and environmental variables at the plot level. Forest age class represented by symbols: Circles $=(8 \mathrm{YAH})$; squares $=(15 \mathrm{YAH})$; diamonds $=(25 \mathrm{YAH})$; rectangles $=(60 \mathrm{YAH})$. Host tree species labelled by colours and letters: $\mathrm{E}=$ Erica arborea $(\mathrm{grey}$ symbols $) ; \mathrm{L}=$ Laurus novocanariensis (empty symbols); $\mathrm{M}=$ Myrica faya (black symbols). For more detail about bryophyte parameters see Table III.

availability) between "old-growth" and secondary forests. In many cases, such differences might cause the loss of particular forest-dwelling species (Dynesius and Hylander, 2007; Lesica et al., 1991; McGee and Kimmerer, 2002), or even the occasional local extinction of entire taxonomic groups (Gjerde et al., 2005; Moen and Gunnar-Jonsson, 2003).

Certain "old-growth" and/or climatically more favourable Canarian laurel forests (González-Mancebo et al., 2008a) exhibit bryophyte richness similar to that found in the oldest forest age class that we studied (60 YAH). This remains true even when individual tree species are considered (González-Mancebo et al., 2003a; 2003b). In contrast, bryophyte biomass values from the oldest forests $\left(1.2 \mathrm{tha}^{-1}\right.$; Tab. IV) in our study were much lower than indirect estimates from other "old-growth" laurel forests (Zippel, 1998), which ranged from 5 to $7 \mathrm{t} \mathrm{ha}^{-1}$. Moreover, our total biomass estimate for $60 \mathrm{YAH}$ was close to that reported for a comparable forest in the vicinity of our oldest forests $\left(1.6 \mathrm{t} \mathrm{ha}^{-1}\right.$; Zippel, 1998). This suggests that both methods may be useful, at least for laurel forests with a limited bryophyte-biomass canopy on the windward side of the islands.

Hence, species richness apparently rose faster than biomass through the chronosequence. This may be partly related to dispersal processes, since it seems unlikely that the distances between secondary forest stands (from 20 to $1092 \mathrm{~m}$ ) would be so significant as to prevent the arrival of propagules. Several studies (Hutsemekers et al., 2008; Miller \& McDaniel, 2004) have shown that the recruitment of some bryophyte species from source populations placed within a range of at least 5$86 \mathrm{~km}$ occurred within a period that could range from $\sim 50$ to $65 \mathrm{y}$. In addition, the small logs and branches that remain in the cleared stands could act as additional diaspore sources (Humphrey et al., 2002). It should be acknowledged that the positive dispersal effect and, hence, the high species richness may be artefacts of the study system rather than a general feature of secondary laurel forest patches.

Furthermore, climatic factors might also underlie the relatively low biomass (cf. Frahm and Gradstein, 1991). Indeed, laurel forests that exhibited greater bryophyte biomass (Zippel, 1998) than the oldest forests studied here were at altitudes ranging from $\sim 800$ to $1200 \mathrm{~m}$ a.s.l. and were topographically situated close to mountain peaks. Our forests were located at a similar altitude (ca. $1200 \mathrm{~m}$ ), but they were distant from the summit (ca. $1700 \mathrm{~m}$ ) and were seldom affected by prevailing NE winds during the summer (Marzol, 2008). This combination of climate and topography would imply less mist precipitation and consequently reduced availability of water for bryophyte (re-) growth.

In conclusion, we suggest the existence of a secondary successional stage in our oldest forest age class (60 YAH), which 

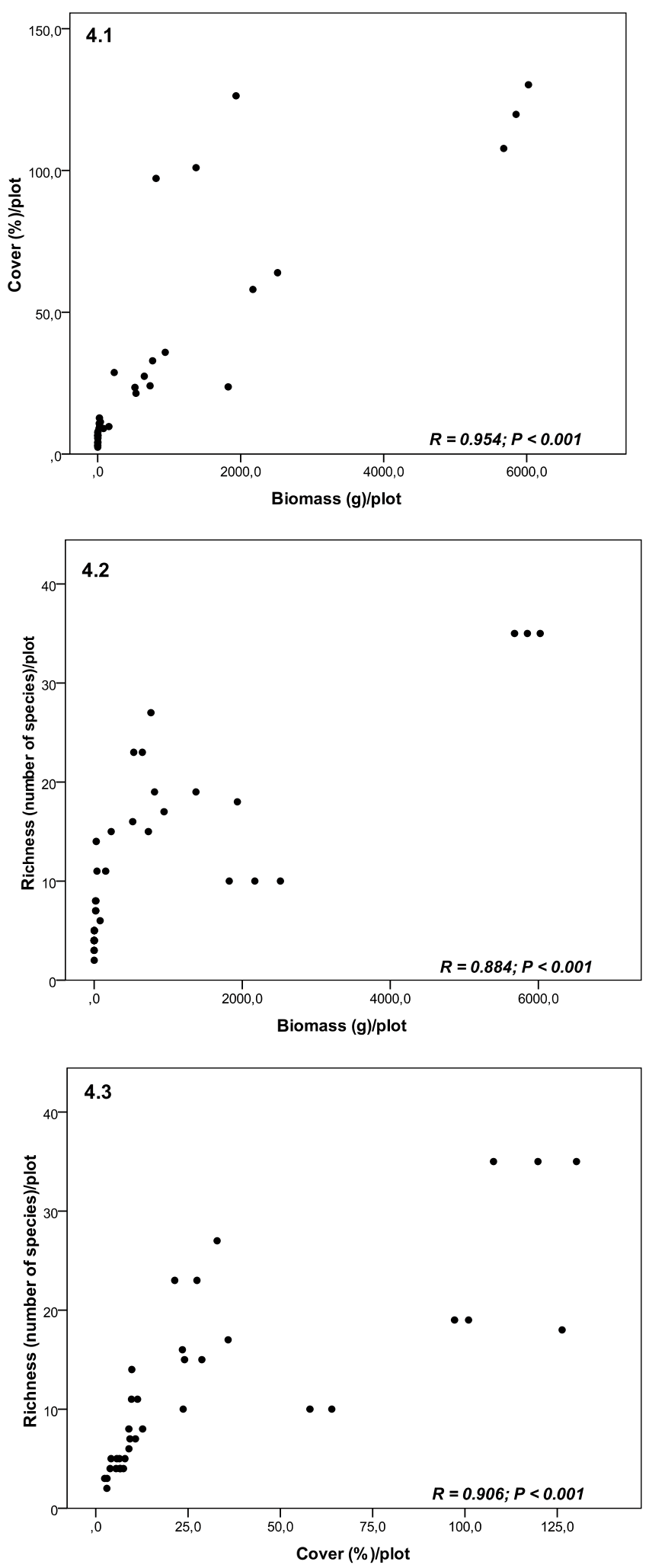

Figure 4. The relationship between biomass and cover (4.1), biomass and species richness (4.2) and cover and species richness (4.3) of epiphytic bryophytes at the plot level. Each host tree species was considered separately $(n=36)$. Spearman Rank correlation results are showed within each diagram. supports previous work on community composition (Patiño et al., 2009). Three factors seem to support this observation. First, our findings showed greater epiphyte biomass (as well as cover and richness) on trunks as compared with branches. Notably, the biomass obtained for the branch system might be overestimated slightly due to the sampling method (see the sampling section). In contrast, "old-growth" (sub-)tropical cloud forests usually support greater bryophyte development on their inner branch systems due to a more favourable microclimate (Chia-Chun et al., 2002; Nadkarni et al., 2004; Veneklaas et al., 1990; Wolf, 1993). Other data suggest inner canopy zones exhibit the richest epiphytic bryophyte communities in comparable laurel forest areas (Patiño et al., unpublish. data).

Second, the differences in biomass, cover and richness of epiphytes throughout whole trees decreased from the youngest to the oldest forests. The latter observation is consistent with the classical pattern where bark-colonisation by bryophytes and lichens progresses upwards over time (McCune, 1993; Wolf, 1993). Third, a period of $60 \mathrm{y}$ following disturbance could represent only $\sim 40 \%$ of the potential life-span of a tree for the three species analysed (Fernández-López, comm. pers.). Under such conditions, one could expect even most of the oldest trees to have an immature tree structure and, hence, (micro-)environmental conditions that might be unsuitable for the development of certain epiphytic bryophytes (Dynesius and Hylander, 2007; Köhler et al., 2007). This would explain, at least partially, the low epiphytic biomass detected in the $60 \mathrm{YAH}$ forests.

\subsection{Influence of host tree species and zone within the tree}

Contradicting the initial hypothesis, our findings showed that the epiphytic community seemed to be more strongly affected by host identity than by forest age. Indeed, different rise patterns were recorded with respect to biomass for epiphytic bryophyte cover and richness, depending on the host tree species.

Laurus novocanariensis showed the greatest biomass and richness across most forest ages, especially at 60 YAH. Poikilohydric non-vascular epiphytes like bryophytes are particularly sensitive to environmental conditions and therefore depend on humidity, temperature and light for their survival (Frahm and Gradstein, 1991; Humphrey et al., 2002; Köhler et al., 2007; Pereira and Cavalcanti, 2007). Thus, individual characteristics of L. novocanariensis, such as its high rate of stem-flow and leaf size (i.e. high water and moderate light incidence) have been related to its notable bryophyte richness (González-Mancebo et al., 2004; 2008a). In our study, this was consistent with a more rapid increase in biomass and species richness along the tree after clear-cutting. This favourable microclimate on $L$. novocanariensis would allow for the development of bryophyte biomass on even the youngest branches and twigs.

In contrast, Myrica faya and Erica arborea were generally poorer in terms of epiphytic bryophyte richness and 
less well-colonised (i.e. bryophytes reached only the middle and inner canopy, respectively). This may be related to more challenging moisture conditions for bryophytes (González-Mancebo et al., 2003a). Since both host tree species have exhibited greater species richness in undisturbed laurel forests (González-Mancebo et al., 2003b; 2008a), they likely need more time than $L$. novocanariensis to recover the peak values for these parameters. In $M$. faya, poor colonisation by epiphytic bryophytes was most evident at $60 \mathrm{YAH}$. This decrease occurred in parallel with a basal area reduction that might be effectively limited by competition with $L$. novocanariensis (Arévalo et al., 1999).

\subsection{Relationships between biomass and species richness of bryophytes}

There was a clear positive relationship between biomass and richness of epiphytic bryophytes across the chronosequence; cover was also considered. There exist reports of a wide variety of relationships between richness and productivity (for biomass per surface unit in our case). These are associated with factors such as the spatial scale, taxonomic group, or ecosystem. The productivity-richness relationship is generally hump-shaped (unimodal) in plant studies and on relatively small spatial scales (Waide et al., 1999; Mittelbach et al., 2001), with species richness peaking at mid-range levels of productivity (Gjerde et al., 2005; Groner and Novoplansky, 2003).

The positive relationship between biomass and richness that we reported may be interpreted as another indicator of immaturity, even for the $60 \mathrm{YAH}$ forests. We propose this explanation because one would expect a negative correlation between richness and biomass when the forest reaches original condition. However, our results should be treated with caution, since new studies must be undertaken in different laurel forests before we can draw firm conclusions regarding the biomass-richness relationships of epiphytic bryophytes.

In contrast to stand level and $L$. novocanariensis data, E. arborea and M. faya showed a decrease in richness with increasing biomass. This unimodal pattern might be considered an indicator of forest maturity. However, since the richness on E. arborea and M. faya did not peak, it is likely that such decreases in the first two species are due to changes in substrate availability consistent with laurel forest dynamics (Arévalo et al., 1999). Competitive exclusion due to early-successional bryophyte species may also play a role (Hutsemekers et al., 2008; Patiño et al., 2009). Gjerde et al. (2005) showed that sensitivity to disturbance of certain organisms could be one possible explanation for unusual patterns.

\subsection{Management implications}

Our findings are relevant for secondary sub-tropical cloud forests, where trunk colonisation by bryophytes does not appear to begin until $8 \mathrm{YAH}$. Using a theoretical successional approach, the $60 \mathrm{YAH}$ forests would be categorised as being in the second phase (i.e. medium-late stage), with bryophyte biomass peaking on trunks. Hence, the current harvesting regime of 7-10 y is clearly too short to allow epiphytic "bryomass" to reach a level of development comparable to that found in "old-growth" laurel forests (Zippel, 1998). In such a scenario, epiphytic bryophyte communities may have difficulty performing their important ecological functions, especially in the context of water and nutrient fluxes. In conclusion, our study indicates that longer rotation periods should be used across harvested laurel forest landscapes. This outcome is consistent with those studies of epiphyte bryophytes that have been conducted in diverse forest ecosystems (Dynesius and Hylander, 2007; Kantvilas and Jarman, 2004; Köhler et al., 2007; Turner and Pharo, 2005).

However, current commercial requirements do not realistically allow managers to change the short rotation cycle that is currently in widespread use (Bermúdez et al., 2007). Accordingly, it is essential to consider retaining mature patches within the matrix of cleared stands. Such a management strategy has also been recommended for many other forest types (e.g. Boudreault et al., 2000; McGee and Kimmerer, 2002; Turner and Pharo, 2005) because it allows maintenance of a significant diversity of substrates and (micro-)habitats.

Due to their high bryophyte biomass and richness, mature Laurus novocanariensis trees might also act as propagule sources in adjacent forest landscapes that have been recently clear-cut. Furthermore, preserving old trees of different host tree species would provide additional value, because certain species apparently require longer time periods (sometimes more than 60 y) to reach comparable biomass and bryophyte species richness. This is especially true for inner canopies. Since there is clearly an incentive to maintain net epiphyte biodiversity in harvested cloud forest landscapes (e.g. Köhler et al., 2007), our results suggest that this can be achieved by preserving "old-growth" uncut stands that exhibit as much original host tree diversity as possible.

Acknowledgements: We wish to thank Ana Losada-Lima and Francisco Lara for revising some specimens, Elke Zippel for English translation of her study and Manuel Nogales for interesting statistical comments. Ángel Fernández-López provided interesting data on the life-span of the tree species. We especially thank Julio Leal, the environmental teams and Violeta Alonso for their help during fieldwork. Constructive comments from four previous anonymous reviewers, David E. Hibbs, Gilbert Aussenac, Monique Pitsch and Erwin Dreyer have greatly improved the manuscript. This work was partly funded by the Government from Canary Islands (grant TES2005/086).

\section{REFERENCES}

Acebes J.R., Del Arco M., García A., León M.C., Pérez P.L., Rodríguez O., and Wildpret W., 2004. División Pteridophyta y Spermatophyta. In: Izquierdo I., Martín J.L., Zurita N., and Arechavaleta M. (Eds.), Lista de especies silvestres de Canarias (hongos, plantas y animales terrestres). Consejería de Política Territorial y Medio Ambiente, Spain, pp. 100-140.

Arévalo J.R. and Fernández-Palacios J.M., 1998. Treefall gap characteristics and regeneration in the laurel forest of Tenerife. J. Veg. Sci. 9: 297-306. 
Arévalo J.R., Fernández-Palacios J.M., and Palmer M.W., 1999. Tree regeneration and future dynamics of the laurel forest on Tenerife, Canary Islands. J. Veg. Sci. 10: 861-868.

Bermúdez A., Fernández-Palacios J.M., González-Mancebo J.M., Patiño J., Arévalo J.R., Otto R., and Delgado J.D., 2007. Floristic and structural recovery of a laurel forest community after clear cutting: A 60 y chronosequence on La Palma (Canary Islands). Ann. For. Sci. 64: 109-119.

Boudreault C., Gauthier S., and Bergeron Y., 2000. Epiphytic lichens and bryophytes on Populus tremuloides along a chronosequence in the southwestern boreal forest of Québec, Canada. Bryologist 103: $725-738$.

Cabrera J.C., 2001. Poblamiento e impacto aborigen. In: FernándezPalacios J.M., and Martín J.L. (Eds.), Naturaleza de las Islas Canarias. Ecología y Conservación. Turquesa, Santa Cruz de Tenerife, pp. 241-245.

Chang S.C., Lai I.L., and Wu J.T., 2002. Estimation of fog deposition on epiphytic bryophytes in a subtropical montane forest ecosystem in northeastern Taiwan. Atm. Res. 64: 159-167.

Chia-Chun H., Fu-Wen H., and Chen-Meng K., 2002. Epiphyte biomass and nutrient capital of a moist subtropical forest in north-eastern Taiwan. J. Tropical Ecol. 18: 659-670.

Clarke K.R., 1993. Non-parametric multivariate analyses of changes in community structure. Australian J. Ecol. 18: 117-143.

Clarke K.R. and Corley R.N., 2006. PRIMER v6: User Manual/Tutorial. PRIMER-E, Plymouth

Del Arco M., Acebes J.R., Pérez de Paz P.L., and Marrero M.C., 1999. Bioclimatology and climatophilous vegetation of Hierro (part 2) and La Palma (Canary Islands). Phytocoenologia 29: 253-290.

Del Arco, M., Wildpret, W., Pérez De Paz, P.L., Rodríguez-Delgado, O., Acebes, J.R., García-Gallo, A., Martín, V.E., Reyes-Betancourt, J.A., Salas, M., Bermejo, J.A., González, R., Cabrera, M.V., and García, S., 2006. Mapa de vegetación de Canarias. GRAFCAN, Santa Cruz de Tenerife, Spain.

Dynesius M. and Hylander K., 2007. Resilience of bryophyte communities to clear-cutting of boreal stream-side forests. Biol. Conserv. 135: 423-434.

Edwards P.J. and Grubb P.J., 1977. Studies of mineral cycling in a montane rain forest in new Guinea. I. The distribution of organic matter in the vegetation and soil. J. Ecol. 65: 943-969.

Fernández-López A.B., 2001. Conservación y restauración ecológica de los bosques. In: Fernández-Palacios J.M., and Martín J.L. (Eds.), Naturaleza de las Islas Canarias. Ecología y conservación. Turquesa, Santa Cruz de Tenerife, pp. 375-382.

Fernández-Palacios J.M., Vera A., and Brito A., 2001. Los ecosistemas. In: Fernández-Palacios J.M. and Martín J.L. (Eds.), Naturaleza de las Islas Canarias. Ecología y Conservación, Turquesa. Santa Cruz de Tenerife, pp. 157-164.

Fernández-Palácios J.M. and Whittaker R.J., 2008. The Canaries: an important biogeographical meeting place. J. Biogeogr. 35: 379-387.

Foster B.L. and Tilman D., 2000. Dynamic and static view of succession: Testing the descriptive power of the chronosequence approach. Plant Ecol. 146: 1-10.

Frahm J.P. and Gradstein S.R., 1991. An altitudinal zonation of tropical rain forests using bryophytes. J. Biogeogr. 18: 669-676.

Gabriel R. and Bates J.W., 2005. Bryophyte community composition and habitat specificity in the natural forests of Terceira, Azores. Plant Ecol. 177: 125-144.

Gjerde I., Sætersdal M., Rolstad J., Storaunet K.O., Blom H.H., Gundersen V., and Heegaard E., 2005. Productivity-diversity relationships for plants, bryophytes, lichens, and polypore fungi in six northern forest landscapes. Ecography 28: 705-720.

González-Mancebo J.M., Losada-Lima A., and McAlister S., 2003a. Host specificity of epiphytic bryophyte communities of a laurel forest on Tenerife (Canary Islands, Spain). Bryologist 106: 383-394.
González-Mancebo J.M., Losada-Lima A., and Patiño J., 2003b. Sobre la variación de la biodiversidad de briófitos en el Parque nacional de Garajonay (La Gomera, Islas Canarias). Análisis preliminar. Vieraea 31: 421-445.

González-Mancebo J.M., Romaguera F., Losada-Lima A., and Suárez A., 2004. Epiphytic bryophytes growing in Laurus azorica (Seub.) Franco in three laurel forest areas in Tenerife (Canary Islands). Acta Oecol. 25: 159-167.

González-Mancebo J.M., Losada-Lima A., Patiño J., and Leal J., 2008a. Los briófitos del Parque Nacional de Garajonay. In: Beltrán E. (Ed.), Hongos, líquenes y briófitos del Parque Nacional de Garajonay. Organismo Autónomo de Parques Nacionales, Madrid, pp. 565-775.

González-Mancebo J.M., Romaguera F., Ros R.M., Patiño J., and Werner O., 2008b. The bryophyte flora of the Canary Islands: update of the species list, and island distribution patterns in the context of the Macaronesian Region. Cryptog., Bryol. 29: 315-357.

Groner E. and Novoplansky A., 2003. Reconsidering diversityproductivity relationships: directness of productivity estimates matters. Ecol. Letters 6: 695-699.

Hofstede R.G.M., Wolf J.H.D., and Benzing D.H., 1993. Epiphytic mass and nutrient status of an Upper Montane Rain Forest. Selbyana 14: $37-45$.

Hutsemekers V., Dopagne C., and Vanderpoorten A., 2008. How far and how fast do bryophytes travel at the landscape scale? Divers. Distrib. 14: 483-492.

Humphrey J.W., Davey S., Peace A.J., Ferris R., and Harding K., 2002. Lichens and bryophyte communities of planted and semi-natural forests in Britain: the influence of site type, stand structure and deadwood. Biol. Conserv. 107: 165-180.

Hylander K., Dynesius M., Jonsson B.G., and Nilsson C., 2005. Substrate form determines the fate of bryophytes in riparian buffer strips. Ecol. Appl. 15: 674-688.

Johansson D., 1974. Ecology of vascular epiphytes in West African rain forest. Acta Phytog. Suecica 59: 1-136.

Johnson E.A. and Miyanishi K., 2008. Testing the assumptions of chronosequences in succession. Ecol. Letters 11: 419-431.

Kantvilas G. and Jarman S.J., 2004. Lichens and bryophytes on Eucalyptus obliqua in Tasmania: management implications in production forests. Biol. Conserv. 117: 359-373.

Köhler L., Tobón C., Frumau K.F.A., and Bruijnzeel L.A. (Sampurno), 2007. Biomass and water storage dynamics of epiphytes in oldgrowth and secondary montane cloud forest stands in Costa Rica. Plant Ecol. 193: 171-184.

Legendre P. and Legendre L., 1998. Numerical ecology. 2nd English edition, Elsevier Science BV, Amsterdam, 853 p.

Lesica P., McCune B., Cooper S.V., and Schic-Hong W., 1991. Differences in lichens and bryophytes communities between old-growth and managed second-growth forest in the Swan Valley Montana. Can. J. Bot. 69: 1745-1755.

Martín J.L., Marrero M., Zurita N., Arechavaleta M., and Izquierdo I., 2005. Biodiversidad en gráficas. Especies silvestres de las Islas Canarias, Consejería de Medio Ambiente y Ordenación del Territorial, Gobierno de Canarias, Spain, 55 p.

Marzol M.V., 2008. Temporal characteristics and fog water collection during summer in Tenerife (Canary Islands, Spain). Atmosph. Res. 87: $352-361$.

McCune B., 1993. Gradients in epiphyte biomass in three PseudotsugaTsuga forests of different ages in western Oregon and Washington. Bryologist 96: 405-411.

McGee G.G. and Kimmerer R.W., 2002. Forest age and management effects on epiphytic bryophyte communities in Adirondack northern hardwood forests, New York, USA. Can. J. For. Res. 32: 1562-1576.

Médail F. and Quézel P., 1997. Hot-spots analysis for conservation of plant biodiversity in the Mediterranean basin. A. Missouri Botanical Garden 84: 112-127. 
Miller N.G. and McDaniel S.F., 2004. Bryophyte dispersal capabilities inferred from colonization of an introduced substrate on Whiteface Mountain, New York Am. J. Bot. 91: 1173-1182.

Minchin P.R., 1987. An evaluation of the relative robustness of techniques for ecological ordination. Vegetatio 69: 89-107.

Mittelbach G.G., Steiner C.F., Scheiner S.M., Gross K.L., Reynolds H.L., Waide R.B., Willig M.R., Dodson S.I., and Gough L., 2001. What is the observed relationship between species richness and productivity? Ecology 82: 2381-2396.

Moen J. and Jonsson B.G., 2003. Edge effects on liverworts and lichens in forest patches in a mosaic of boreal forest and wetland. Conserv. Biol. 17: 380-388.

Nadkarni N.M., Merwin M.C., and Nieder J., 2001. Forest canopies: plant diversity. In: Levin S. (Ed.), Encyclopedia of biodiversity, Academic Press, San Diego, pp. 27-40.

Nadkarni N.M., Schaefer D.A., Matelson T.J., and Solano R., 2004. Biomass and nutrient pools of canopy and terrestrial components in a primary and a secondary montane cloud forest, Costa Rica. For. Ecol. Manage. 198: 223-236.

Naranjo J., 2001. Los aprovechamientos forestales. In: FernándezPalacios J.M., and Martín J.L. (Eds.), Naturaleza de las Islas Canarias. Ecología y Conservación, Turquesa, Santa Cruz de Tenerife, pp. 269-274.

Patiño J., González-Mancebo J.M., and Fernández-Palacios J.M., 2009. Epiphytic bryophytes in canarian subtropical montane cloud forests: the importance of the time since disturbance and host identity. Can. J. For. Res. 39: 48-63.

Pereira L. and Cavalcanti K., 2007. Patch size and isolation effects on epiphytic and epiphyllous bryophytes in the fragmented Brazilian Atlantic forest. Biol. Conserv. 134: 415-427.
Pickett S.T.A., 1989. Space-for-time substitution as an alternative to longterm studies. In: Likens G.E. (Ed.), Long-term studies in ecology, Springer Verlag, New York, pp. 110-135.

Pócs T., 1980. The epiphytic biomass and its effect on the water balance of two rainforest types in the Uluguru Mountains. Acta Bot. Acad. Sci. Hung. 26: 143-167.

SPSS, 2008. SPSS/PC+ V17.0. Base Manual. SPSS Inc., Chicago, IL.

Ter Braak C.J.F. and Šmilauer P., 2002. CANOCO Reference manual and CanoDraw User's Guide: Software for Canonical community ordination (Version 4.5). In: Microcomputer Power. Ithaca, NY, $4351 \mathrm{p}$.

Turner P.A.M. and Pharo E.J., 2005. Influence of substrate type and forest age on bryophyte species distribution in Tasmanian mixed forest. Bryologist 108: 67-85.

Veneklaas E.J., Zagt R.J., Van Leerdam A., Van Ek R., Broekhoven A.J., and Van Genderen M., 1990. Hydrological properties of the epiphyte mass of a montane tropical rain forest. Vegetatio 89: 183-192.

Waide R.B., Willig M.R., Steiner C.F., Mittelbach, G., Gough L., Dodson S.I., et al., 1999. The relationship between productivity and species richness. Annu. Rev. Ecol. Syst. 30: 257-300.

Wolf J.H.D., 1993. Ecology of epiphytes and epiphyte communities in montane rain forests, Colombia. Ph.D. thesis, University of Amsterdam, Elinkwijk, B.V., 238 p.

Zippel E., 1998. Die epiphytische Moosvegetation der Kanarischen Inseln. Soziologie, Struktur und Ökologie, Bryophytorum bibliotheca, Band 52, J. Cramer, Berlin, 149 p. 